\title{
Recent advances in lipid droplet biology
}

Citation for published version (APA):

Coleman, R. A., \& Hesselink, M. K. (2017). Recent advances in lipid droplet biology. Biochimica et Biophysica Acta-Molecular and Cell Biology of Lipids, 1862(10), 1129-1130.

https://doi.org/10.1016/j.bbalip.2017.08.002

Document status and date:

Published: 01/10/2017

DOI:

10.1016/j.bbalip.2017.08.002

Document Version:

Publisher's PDF, also known as Version of record

Document license:

Taverne

Please check the document version of this publication:

- A submitted manuscript is the version of the article upon submission and before peer-review. There can be important differences between the submitted version and the official published version of record.

People interested in the research are advised to contact the author for the final version of the publication, or visit the DOI to the publisher's website.

- The final author version and the galley proof are versions of the publication after peer review.

- The final published version features the final layout of the paper including the volume, issue and page numbers.

Link to publication

\footnotetext{
General rights rights.

- You may freely distribute the URL identifying the publication in the public portal. please follow below link for the End User Agreement:

www.umlib.nl/taverne-license

Take down policy

If you believe that this document breaches copyright please contact us at:

repository@maastrichtuniversity.nl

providing details and we will investigate your claim.
}

Copyright and moral rights for the publications made accessible in the public portal are retained by the authors and/or other copyright owners and it is a condition of accessing publications that users recognise and abide by the legal requirements associated with these

- Users may download and print one copy of any publication from the public portal for the purpose of private study or research.

- You may not further distribute the material or use it for any profit-making activity or commercial gain

If the publication is distributed under the terms of Article $25 \mathrm{fa}$ of the Dutch Copyright Act, indicated by the "Taverne" license above, 
Editorial

\section{Recent advances in lipid droplet biology}

Since antiquity, the presence of excess adipose tissue has been identified as a cause of poor health and diminished longevity. Hippocrates wrote, "It is very injurious to health to take in more food than the constitution will bear, when, at the same time one uses no exercise to carry off this excess" [1]. Although similar ideas recorded through the centuries continued to expose the health hazards of obesity [2], our current understanding of why excess fat accumulation is injurious has required multiple technical advances. These include the ability to separate different forms of lipids, the development of histological techniques, the recognition that triacylglycerol (TAG) accumulation is associated with insulin resistance and the metabolic syndrome, the identification of enzymes of TAG synthesis and degradation, and finally, the realization that lipid droplets (LDs) are not just accumulations of inert lipid, but are, in fact, functional cellular organelles.

LDs were first noticed in cells in the 1880s when "lifeless food-matter" was described in egg yolk and egg cytosol as "fat-drops", "oil-drops," or "fatty deutoplasm-spheres" [3] and in frog fatty liver [4]. After these initial histological descriptions, LDs were noted in a variety of tissues, including the adrenal gland in which they were believed to represent a "glandular product" [5]. In the 1950s and 60s, when intracellular structures could be visualized by electron microscopy, conflicting views arose as to the origin of LDs, including their possible derivation from microbodies that were also the source of mitochondria [6,7] or their development in intracisternal spaces of the endoplasmic reticulum [8]. LDs were notable in regenerating liver after partial hepatectomy [9], where they were thought to be taken up by pinocytosis and perhaps then oxidized, since they seemed to associate with mitochondria [10]. Pinocytosis of tiny, unobservable LDs was also believed to occur in intestinal epithelial cells after a fatty meal [11]. It was recognized that the origin of LDs differed from that of lipoprotein particles because when isolated perfused livers were incubated with puromycin to block protein synthesis, only the production of lipid within the secretory apparatus was inhibited [12]. The fate of LDs was also a matter of contention. For example, it was considered likely that after cream feeding, tiny lipid droplets might enter intestinal mucosal cells, coalesce, and then reach the Golgi complex intact for secretion into the lymph [11,13].

Meanwhile, biochemical studies determined the location of TAG synthesis. Autoradiography after injections of tritiated glucose indicated that TAG was synthesized in the endoplasmic reticulum of intestinal epithelial cells [14] and liver [8]. The endoplasmic reticulum location was confirmed by showing that, apart from phosphatidic phosphohydrolase, all the enzymes of TAG and phospholipid synthesis were present in liver microsomal fractions [15].

In spite of the fact that they were present in virtually every cell, little attention was paid to the LDs themselves, apart from recognition that their fatty acid content was a cellular source of energy and contributed to the synthesis of the TAG that was secreted in lipoproteins and milk. The origin of LDs was of little interest until the discovery in 1991 of the first droplet-specific protein, the heavily phosphorylated perilipin 1 (PLIN1) [16]. Since then, interest in LDs has grown dramatically because of their relationship to insulin resistance, their use as fuels, their use in specialized programs of autophagy and exosome production, their function as organizational centers or scaffolds for the construction of virus particles, and their ability to release signaling molecules and transcription factor ligands. Hoping to present some of the newest and most interesting areas in lipid droplet research, we invited speakers from the 2016 FASEB Summer Conference on Lipid Droplets: Dynamic Organelles in Metabolism and Beyond to place their novel findings in a more general context and to identify critical areas that require additional attention.

Numerous synthetic and lipolytic enzymes are required to store or degrade neutral lipids. Karen Reue and her colleagues review the three lipin/ phosphatidic phosphohydrolases that convert phosphatidic acid (PA) to diacylglycerol to regulate the synthesis of TAG and the major phospholipids. Jun Liu and his colleagues update information on G0S2, which is a major regulator of ATGL, the primary LD TAG lipase. Focusing on sphingolipid metabolism, Mariana Nikolova-Karakashian and Gergana Deevska provide a comprehensive overview of the role of sphingolipids in LD biogenesis.

Interest in the cell biology of LDs is growing, particularly their roles in autophagy, as discussed by Kirill Bersuker and James Olzmann, and in lipophagy, discussed by Douglas Mashek and his colleagues. Maya Schuldiner and Maria Bohnert provide new insights on the emerging concept that LDs dynamically form and dissolve contact sites with other organelles, Peng Li and her colleagues focus on Cidec and its role in LD fusion, and Xiao Chen and Joel Goodman discuss the contributions of seipin, perilipin, and the Fit proteins in LD assembly.

Proteomics studies have identified a multitude of specific LD proteins, and we asked Sander Kersten and Monserrat de la Rosa Rodriquez to discuss the regulation of several of these proteins by PPAR $\alpha$, PPAR $\delta$, and PPAR $\gamma$ in adipose tissue, liver, macrophages and skeletal muscle. Dawn Brasaemle and Carole Sztalryd focus on the PLIN proteins, and Mark Brown and Amanda Brown bring us up to date on CGI-58 and its roles in lipolysis and energy homeostasis.

LDs perform several specialized roles in cells. Matthijs Hesselink and Bret Goodpaster explore the role of LDs and related parameters that affect the insulin sensitivity of human muscle cells as well as novel imaging based tools to study these parameters. Matt Watt and Yunsheng Cheng focus on the metabolism of muscle neutral lipids during exercise. Michael Welte and Alex Gould discuss functions of LDs that do not involve energy storage, and Hongyuan Robert Yang examines the problem of seipin-related lipodystrophy and the role of phosphatidic acid in forming huge lipid droplets.

Because LD metabolism in non-mammalian organisms is of considerable interest, we are sorry to have had to omit important recent studies on plant LDs $[17,18]$. We also regret that we have not been able to include all the exciting developments in the LD field, but wish to highlight recent 
excellent reviews on specialized topics, including lipid degradation [19], LDs and liver disease [20], the roles of major phospholipids [21], LD diversity [22], and the requirement for LDs by replicating intracellular pathogens [23].

\section{Acknowledgement}

This work was supported by a grant from the National Institutes of Health (DK56598) and by support from the Netherlands Cardiovascular Research Initiative: an initiative with support of the Dutch Heart Foundation (CVON2014-02 ENERGISE)

\section{References}

[1] D. Haslam, Obesity: a medical history, Obes. Rev. 8 (Suppl. 1) (2007) 31-36.

[2] D. Haslam, The history of obesity, Clin. Obes. 1 (2011) 189-197.

[3] E.B. Wilson, The Cell in Development and Inheritance, Macmillan and Co., Ltd., London, 1897.

[4] R. Altmann, Die Elementarorganisem und ihre Beziehungen zu den Zellen, Verlag von Veit \& Comp., Leipzig, 1890.

[5] J.F. David-Ferreira, Augusto Celestino da Costa (1884-1956) — professor, scientist and science promoter, Int. J. Dev. Biol. 53 (2009) $1161-1164$.

[6] W.D. Belt, The origin of adrenal cortical mitochondria and liposomes: a preliminary report, J. Biophys. Biochem. Cytol. 4 (1958) 337-340.

[7] R.A. Knouff, F.A. Hartman, A microscopic study of the adrenal of the brown pelican, Anat. Rec. 109 (1951) 161-188.

[8] O. Stein, Y. Stein, Lipid synthesis, intracellular transport, storage, and secretion. I. Electron microscopic radioautographic study of liver after injection of tritiated palmitate or glycerol in fasted and ethanol-treated rats, J. Cell Biol. 33 (1967) 319-339.

[9] N.L. Trotter, A fine structure study of lipid in mouse liver regenerating after partial hepatectomy, J. Cell Biol. 21 (1964) $233-244$.

[10] N.L. Trotter, Electron-opaque, lipid-containing bodies in mouse liver at early intervals after partial hepatectomy and sham operation, J. Cell Biol. 25 (1965) 41-52 (Suppl).

[11] S.L. Palay, L.J. Karlin, An electron microscopic study of the intestinal villus. II. The pathway of fat absorption, J. Biophys. Biochem. Cytol. 5 (1959) $373-384$.

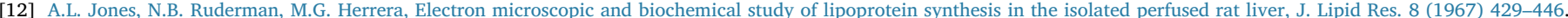

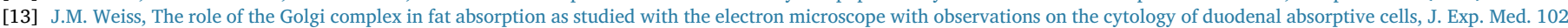
(1955) 775-782.

[14] R.A. Jersild Jr., A radioautographic study of glyceride synthesis in vivo during intestinal absorption of fats and labeled glucose, J. Cell Biol. 31 (1966) $413-427$.

[15] G.F. Wilgram, E.P. Kennedy, Intracellular distribution of some enzymes catalyzing reactions in the biosynthesis of complex lipids, J. Biol. Chem. 238 (1963) 2615-2619.

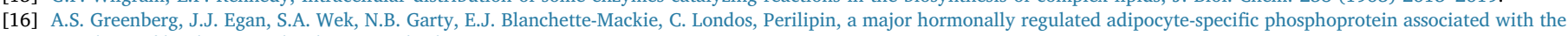
periphery of lipid storage droplets, J. Biol. Chem. 266 (1991) 11341-11346.

[17] M. Pyc, Y. Cai, M.S. Greer, O. Yurchenko, K.D. Chapman, J.M. Dyer, R.T. Mullen, Turning over a new leaf in lipid droplet biology, Trends Plant Sci. (2017).

[18] P.J. Horn, C. Benning, The plant lipidome in human and environmental health, Science 353 (2016) 1228-1232.

[19] A. Meyers, T.M. Weiskittel, P. Dalhaimer, Lipid droplets: formation to breakdown, Lipids 52 (2017) 465-475.

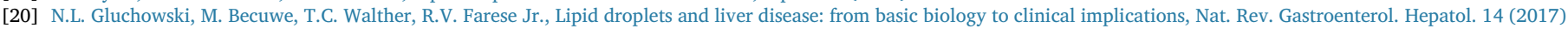
343-355.

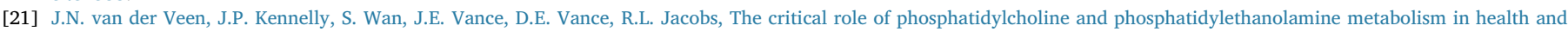
disease, Biochim. Biophys. Acta (2017).

[22] A.R. Thiam, M. Beller, The why, when and how of lipid droplet diversity, J. Cell Sci. 130 (2017) 315-324.

[23] P. Roingeard, R.C. Melo, Lipid droplet hijacking by intracellular pathogens, Cell. Microbiol. 19 (2017).

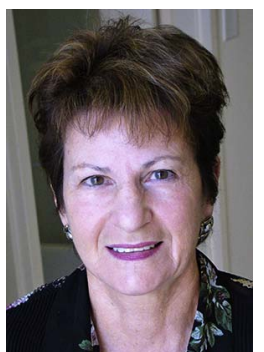

Rosalind Coleman received a B.A. cum laude from Harvard University and an M.D. from Case Western Reserve University. After a pediatric residency at New York Hospital-Cornell Medical Center and Duke University, she completed a clinical fellowship in Endocrinology and Metabolism and a postdoctoral fellowship in Biochemistry at Duke University with Robert M. Bell. In addition to diagnosing and treating children with inborn errors of metabolism, as a faculty member at Duke University and then at the University of North Carolina, she initiated studies of the enzymes of triacylglycerol metabolism in liver and adipose tissue, cloned several acyltransferase isoforms, and investigated tissue-specific knockouts of these enzymes. Currently a professor in the Department of Nutrition, she is continuing to study triacylglycerol biosynthesis and the contributions of individual enzyme isoforms to the development of insulin resistance and diabetes.

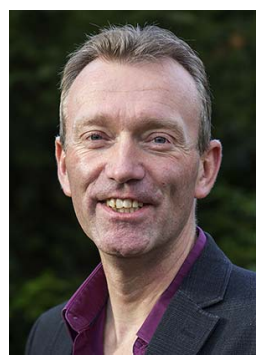

Matthijs Hesselink (1968) is a professor in human movement sciences. In 1992 obtained his PhD at Maastricht University for his thesis on the structural, functional and metabolic aspects of muscle damage. During his post-doctoral training he shifted focus towards (skeletal muscle) insulin resistance. He performed pioneering studies on mitochondrial dysfunction and lipid droplet coat proteins in skeletal muscle of patients with type 2 diabetes. For this, he obtained a prestigious VIDI grant for innovative research from The Netherlands Organization for Scientific Research (NWO). Being appointed at the School of Nutrition and Translational Research in Metabolism (NUTRIM), he is one of the leaders of a translational research team (www.dmrg.nl ) examining subcellular and molecular processes involved in the pathogenesis of insulin resistance, from a whole body (patho)physiology perspective. The composition of his research team, along with the unique infrastructure of the Maastricht University Medical Center permits studying these processes from molecule to man. Dr. Hesselink is active as a (co-)organizer of a variety of international meetings on the cross roads of diabetes, obesity, exercise, nutrition and lipids. On these topics he is also active as a (guest)editor and reviewer for a variety of well-respected journals in the field.

Rosalind A. Coleman* Department of Nutrition, University of North Carolina, Chapel Hill, NC 27599, USA Department of Pediatrics, University of North Carolina, Chapel Hill, NC 27599, USA

E-mail address: rcoleman@unc.edu

Matthijs K. Hesselink Department of Human Biology and Human Movement Sciences, Maastricht University, P.O. Box 616, NL 6200, MD, Maastricht, The Netherlands E-mail address: matthijs.hesselink@maastrichtuniversity.nl

* Corresponding author at: Department of Nutrition, University of North Carolina, Chapel Hill, NC 27599, USA. 